\title{
The Impact of Human Resource Management Practices on the Job Satisfaction of Teachers: A Case of Kalulushi District on the Copperbelt Province of Zambia
}

\author{
Edgar P.C Mwansa ${ }^{1}$, Prof. Sumbye Kapena ${ }^{2}$ \\ ${ }^{1}$ Department of Business and Management Studies, School of Graduate Studies, Copperbelt University, Kitwe \\ ${ }^{2}$ School of Humanities, Copperbelt University, Kitwe
}

\begin{abstract}
The study explored the influence of HR practices on the job satisfaction of teachers in the Kalulushi District in the Copperbelt Province of Zambia. In this cross-sectional study, four dimensions of HR practice namely: Appraisal, Training, Compensation and Planning were used with a total of 100 respondents. The objectives of the study were answered using correlation and regression analysis, and results were also presented using descriptive statistics. All the four dimensions of HR practices were positively related to job satisfaction, with training and development showing the strongest contribution to job satisfaction. Suggestions are made for further research on ways to increase job satisfaction among the employees.
\end{abstract}

Keywords : Teacher satisfaction, human resource management, appraisal, training, compensation and planning practices.

\section{INTRODUCTION}

$\mathrm{T}$ he success of any organization depends largely on the performance of its human resources (Uma et al., 2017.) and the development of any educational institution depends on HRM practices through which teachers are hired, motivated and prepared for serving the institution (Dessler, 2007). Human resource management (HRM) practices are regarded as a set of internally coherent and consistent practices aimed at reinforcing and promoting employee competence, motivation as well as commitment (Elrehail et al., 2019). These practices are vital in that they help in employing skilled, experienced, competent and committed employees that would help the organisation to achieve its goals and objectives. In any organization, employees are considered to be essential strategic assets. Therefore, employees could be a competitive advantage if the organization provides more attention and invest in developing employees' skills at the workplace ( Zaharie and Osoian, 2013). The present study selected the HR practices such as Appraisal, Compensation, training and Planning concerning Job satisfaction. The research was conducted in Kalulushi District which is one of the District centrally located between Kitwe, Chingola, Mufulira, and Lufwanyama Districts in the Copperbelt Province of Zambia. The District has one (1) Constituency with 22 Wards and has an area of about 1,115 square kilometres. Politically, it is a stable and well- coordinated place in terms of governance. The Districtes economy is one of the strongest in the Copperbelt Province due to huge mining investments and is one of the highest contributors in terms of Gross Domestic Products (GDP) and employment. Other small and medium economic activities include small scale mining activities such as silica, retail and informal. Kalulushi has urban and rural settlements and so was chosen as a location for the research.

\section{THEORETICAL BACKGROUND AND RATIONALE OF THE STUDY}

Decenzo and Robbins (1998) defined four basic responsibilities of Human Resource Management: appraisal, training, training and planning. These are the practices of human resources through which employees are considered as an asset to make them motivated and skilled for gaining the organizational goals. Employees' satisfaction increases their commitment, creativity and production for their employers. Job satisfaction is an overall evaluative judgment of a combination of psychological and environmental circumstances that make a person happy with the work performed and creates a positive emotional state regarding the experiences, attitudes and beliefs about the work (Han \& Kakabadse, 2009). Job satisfaction has been one of the major areas of interest in human resource management practice as it reflects employees' attitudes towards their job and commitment to an organization. If teachers are satisfied with their job, they will be more involved in and committed to their profession. Satisfied teachers teach the students with passion and devotion to get the maximum results from students.

\section{PROBLEM STATEMENT}

The Ministry of General Education just like any other Ministry, face challenges, usually caused by complex developments, and technological trends like globalization. These fast changes entail that the Ministry has to effectively manage the teachers to improve on job satisfaction. It is believed that Job satisfaction is inter-linked with performance. When employees are satisfied with their job, they become successfully committed to their organizations and contribute 
to their effectiveness and ultimate survival (Mahmood, 2013). Although HRM practices have increasingly been studied in connection with different organizational outcomes ( Nadarajah et al., 2012;), there has been no research done on how human resource management practices impacts the job satisfaction of teachers in Zambia with a focus on the Kalulushi district of the Copperbelt Province.

\section{METHODOLOGY}

The study employed a survey design and quantitative approach to find out teachers' satisfaction regarding HRM practices. According to the nature of the population, a stratified proportionate sampling technique was adopted for the selection of participants. The total number of participants was 100 in the study and a self-developed research instrument including four HRM practices (Appraisal, Compensation, Training and Planning) were used to collect the data. The instrument was made reliable through pilot testing and valid through expert opinion. Therefore, the researcher collected data through the scheduled timeframe of appointments with teachers in the Kalulushi District of Copperbelt Province.

\section{DATA ANALYSIS AND INTERPRETATIONS}

A. Which human resource management practice is considered most significant by Teachers in Kalulushi District?

\begin{tabular}{|c|c|c|c|c|}
\hline & $\mathrm{N}$ & \multirow{2}{*}{ Mean } & $\begin{array}{c}\text { Std. } \\
\text { Deviation }\end{array}$ & Skewness \\
\cline { 2 - 2 } & Statistic & & Statistic \\
\hline Appraisal & 100 & 4.28 & 2.598 & -.160 \\
\hline Compensation & 100 & 4.62 & 1.819 & -.711 \\
\hline Training & 100 & 5.33 & 2.198 & -1.025 \\
\hline Planning & 100 & 4.74 & 2.250 & -.824 \\
\hline $\begin{array}{c}\text { Valid N } \\
\text { (listwise) }\end{array}$ & 100 & & & \\
\hline
\end{tabular}

The table represents the mean scores and standard deviation from teachers regarding HRM practices. The mean score of teachers regarding human resource management practices of Training was higher as compared to Appraisal, Planning and Compensation Practices. This indicated that the teachers in Kalulushi District tend to be more satisfied with training practices.

B. Which category of teachers in Kalulushi District is more satisfied with human resource practices?

\begin{tabular}{|c|c|c|c|c|c|}
\hline & & $\mathrm{N}$ & Mean & $\begin{array}{c}\text { Std. } \\
\text { Deviation }\end{array}$ & $\begin{array}{c}\text { Std. Error } \\
\text { Mean }\end{array}$ \\
\hline $\begin{array}{c}\text { URBAN } \\
\text { RURAL } \\
\begin{array}{c}\text { SERVICE } \\
\text { QUALITY }\end{array}\end{array}$ & Urban & 72 & 4.17 & 2.484 & .293 \\
\cline { 2 - 6 } & Rural & 38 & 5.16 & 2.366 & .384 \\
\hline
\end{tabular}

The table represents the mean scores and standard deviation of teachers from both Urban and Rural Schools regarding HRM practices. The mean score of teachers from Rural Schools regarding human resource management practices was higher as compared to the mean Score of teachers from Urban

\section{DISCUSSION AND CONCLUSION}

Mean analysis was used to find which practice of human resource management was being considered most satisfactorily and the results were that Training was considered most satisfactory practice. Training in this context is an activity that brings a change in the attitude and behaviour of the individual to increase the capabilities, knowledge and skills to facilitate efficiency and effective learning; that enable the teachers to meet the objectives of the School. There are several training programmes provided by the District to the teachers and these are: on the job training, orientation, safety, promotional, refresher, remedial and others that increase the skills and capability of teachers. Training is also offered through a programme known as Continuous Professional Development (CPD) which is conducted in all the schools and Monitored by the Zonal and District teams. Similarly, mean analysis was used to check which category of teachers were more satisfied with human resource management practices. The mean score of teachers from Rural Schools regarding human resource management practices was higher as compared to the mean Score of teachers from Urban Schools. This was an indication that the teachers from rural Schools were more satisfied with HRM Practices as compared to teachers in Urban Schools. Further, an independent sample ttest was applied for making the comparison of teachers from urban and rural School regarding satisfaction with HR practices. As t-value (3.03) and significance level less at $\mathrm{p} \leq 0.05$. Therefore, a significant difference was recorded in the scores of Urban $(\mathrm{M}=4.17, \mathrm{SD}=2.484)$ and Rural $(\mathrm{M}=5.16$, $\mathrm{SD}=2.366$ ) teachers. So, there was a significant difference between Urban and Rural Teachers. Therefore, the teachers from rural Schools appeared more satisfied with HR practices than the teachers of Urban Schools. Lastly, there was a comparison in terms of Gender. The mean score of male teachers regarding human resource management practices was higher as compared to the mean score of female teachers regarding human resource management practices. This meant that the Male teachers in Kalulushi District were more satisfied with HR practices as compared to Female teachers.

Rapid changes in technology and globalization even change in teachers' demand has brought a revolution in our educational institutions. Teachers have been considered a core component for the progress and credibility of an institution. The current study was conducted on teachers of Kalulushi District to find out their satisfaction regarding HRM practices. The four major HRM practices had a deep influence on the teachers' satisfaction concerning their jobs. Interestingly, the findings had demonstrated that employee training correlates with better firm performance. This is not surprising as past pieces of literature on the wage effects of general and specific training had shown conflicting results (Lynch, 1992; Lowenstein \& Spletzer, 1999; Budria \& Pereira, 2007). 


\section{RECOMMENDATIONS}

Human resources, which are considered the greatest asset of an organization, refer to people whose knowledge, skills, and abilities are utilized to create and deliver effective services. Effective use of HR practices attracts the right quality and quantity of people, develops the knowledge, skills, and abilities of employees, and retains employees within the organization. To improve further, modern technology should be utilized to plan strategically and to develop HR. Moreover, a training and management development program should be implemented to enhance the capabilities of teachers of the Kalulushi district. Investing in the improvement of the knowledge and skills of teachers would enable the district to develop more productive and effective teachers. Keeping in view the above results, discussion and conclusion, the researchers suggested some measures. The district should have a clear indication and structure of human resource management practices. The teachers need to be intimated about their performance and its link with institutional goals and expectations. Besides, the district might organize professional workshops and training sessions for their teachers' satisfaction as well as a transparent performancebased compensation procedure for the teachers.

\section{REFERENCES}

[1] Ahmad, S., \& Schroeder, R. G. (2003). The impact of human resource management practices on operational performance: recognizing country and industry differences, Journal of operations management, 21: 19-43.

[2] Altarawmneh, I. \& Al-Kilani, M. H. (2010). Human resource management and turnover intentions in the Jordanian Hotel Sector. Research and Practice in Human Resource Management, 18(1), 4659 .
[3] Bartlett, K. R. (2001). The relationship between training and organizational commitment: A study in the health care field. Human Resource Development Quarterly, 12(4),335-352.

[4] Chand, M. \& Katou, A. (2007).The impact of HRM practices on organizational performance in the Indian hotel industry, Employee Relations, Vol.29, No.6, pp.576-594.

[5] Dessler, G. (2007).Human resource management, New Delhi: Prentice-Hall of India Private Limited.

[6] Petrescu, A. I. \&Simmons, R. (2008). Human resource management practices and workers' job satisfaction, Int. J. Manpower. 29(7) 651667.

[7] Ting, Y. (1997). Determinants of job satisfaction of federal government employees. Public Personnel Management, 26(3), 313334.

[8] Tzafrir, S. (2005). The relationship between trust HRM practices and firm performance.International Journal of HRM, 16(9), 1600-1622.

[9] Ubom, I. U. \& Joshua, M. T. (2004). Needs Satisfaction Variables as Predictors of Job Satisfaction of Employees: Implication for Guidance and Counseling. EducationalResearch Journal, 4(3).

\section{Author Profile}

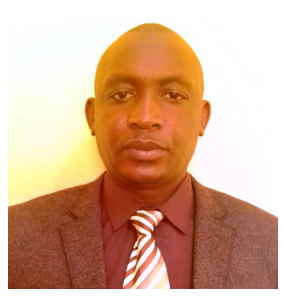

Edgar P.C Mwansa

Born in Zambia, he holds a Master of Business Administration (MBA General), and currently a student of Doctor of Philosophy in Human Resource Management at the Copperbelt University. He obtained his Bachelor of Human Resource Management in 2013, from the Copperbelt University. His interests reside in employee job satisfaction. 